\title{
"SUCANECOS": a sustainable design animated forms theater
}

\author{
Luís Gustavo Ribeiro Noronha ${ }^{1 \mathrm{a}}$ \\ ${ }^{1}$ Francisca de Sousa Peixoto Institute - Cataguases/MG, Brasil.
}

\begin{abstract}
Present paper refers to a sustentainable research work named "Sucanecos", which consists of puppets and dolls eco-designing, with dramaturgical, technical and artistic support directly referenced from the reusal of rejected materials of urban residences and industry.
\end{abstract}

Key words. Eco-Puppet; waste art reusal ; Sustainable animated forms theater; Environmental Art, Eco design theater.

\section{Goals}

The concept of "Sucanecos" was born in 2005 from the need to structure a theatrical production with animated forms (puppets) with aesthetic quality, technical viability and broad repertoire of movements. That is, in short, aiming the avoidance of purchasing new materials, resorting only recyclable waste throught simple articulation mechanisms and available domestic tools.

In this concept, "Sucanecos" would fit in any environment, and could be built by laypeople, educators and artists, thus avoiding the increase of daily waste produced by society that fatefuly is converted into "trash" (a epistemologically problematic matter) and ends up in a landfill.

In economic matters, it adds intrinsic value to materials that until then were objectified as waste. There is, ultimately, a direct and subjacent increment of capital. In the concept of "Sucanecos", the package itself can be worth much more than the product which is just wrapped inside, resignifying economic importance of certain objects in the social structure of materials.

"There is an additional difficulty for those who will be exercising in dramaturgy for puppet theater. There seems to be no other art that contains so many genres and so many techniques. The puppet theater goes from a miniature spectacle with a single puppeteer to theatrical assemblages with dozens of manipulators. He plays small poems and songs on one side, and, on the other hand, classical texts from conventional theater. Contains small exhibitions at parties and outdoor fairs, as it hosts cutting-edge visual and plastic experiments. He approaches the plastic arts when he expresses himself through elaborate forms and light and approaches dance when he relies on movement, pure and simple." (APOCALYPSE, p. 71)

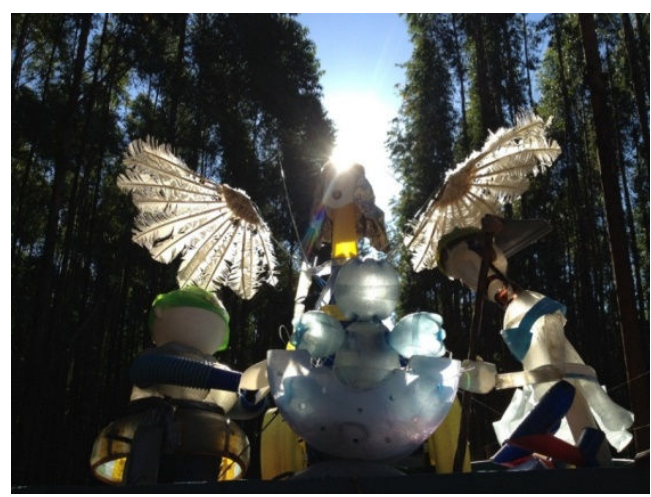

Figure 1. Presépio Móvel, 2017. Personal archive.

\footnotetext{
${ }^{a}$ Corresponding author: gustavonoronha@icloud.com ; +55 35 99969-7222
} 


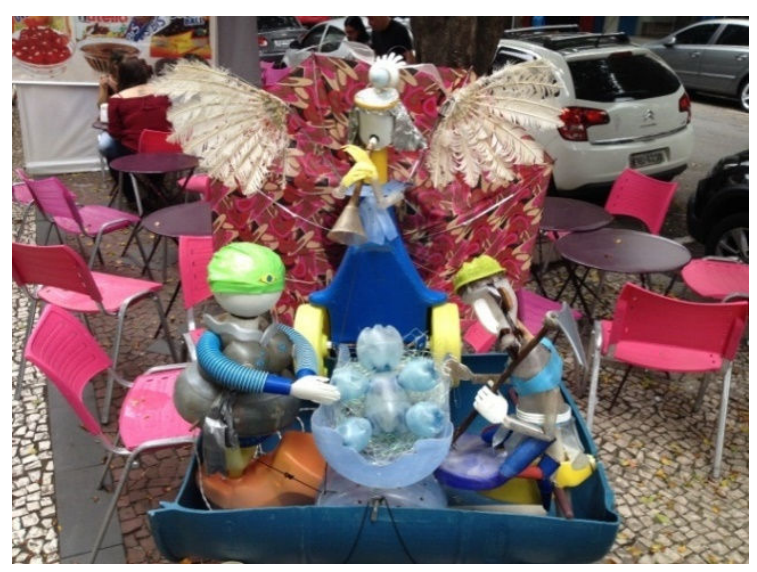

Figure 2. Presépio Móvel, 2017. Personal archive.

\section{Methodology and materials}

We use to say in schools that "the challenge is to let anything get into the landfill. The Garbage is a concept we create - it does not really exist, it's something we awkwardly create. " We took a trash bin from the classroom and found that mixed materials form such a "evil garbage" and if they were not separated they would "die" in the landfill.

Based on this resignification of the trash/garbage concept, everyone is invited (teachers, students, parents, employees) to bring their rejected materials from their homes (cf. MOIN-MOIN, 2006, 2007 e 2008).

During a period of a couple weeks, absolutely everything that can be turned into trash is collected and cleaned, without damaging the materials (packages, recipients, offscourings). Then, we evaluated the shapes, colors, and quantity of each material, discovering the proper dramaturgy regarding specificities, characters and manipulation techniques, creating the bases by crossing the aesthetic data of the materials with the psychological profiles of the characters.

Finally, we set out for construction using only simple tools like scissors, thread, fittings and glues.

Once the character is complete we begin with the manipulation trials and the construction of the scenarios, costumes and props.

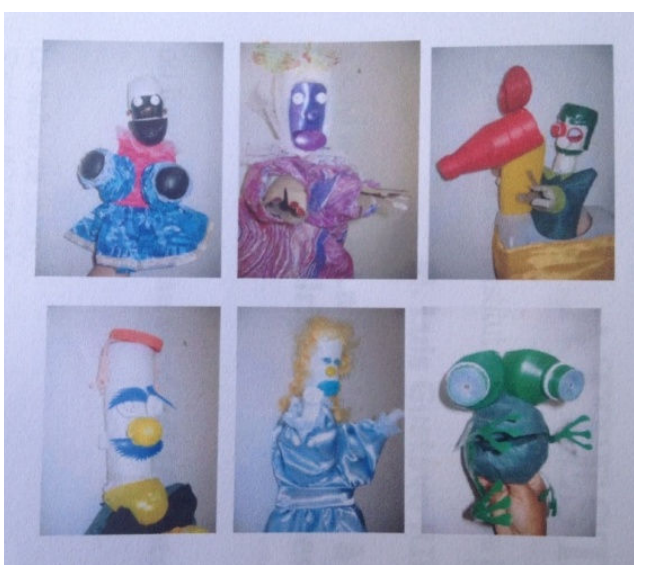

Figure 3. Bonecos de cursos e oficinas. Personal archive.

The courses, assemblage of plays, production of props and training of personnel, are part of our methodology. In this process, we sow sustainable art, with the emergence of new dramaturgic concepts (AMARAL, 1993, 2002). We produced a cutting-edge cultural heritage, after having reviewed all the general techniques of theater manipulation in animated forms and finally having successfully reached the end of the research in 2015 .

\section{Results}

Out from 10 years of research, courses and montages of a considerable collection of works were built. "Sucanecos" approaches all techniques for manipulating puppets and objects (wire, glove, rod, balcony, shadow, automaton, usual and colossal), including a vanguard of contemporary theater that attributes the same dramatic and scenic force to the object, image and Human Body. (CURREL, 2010).

We list below a list of succesful experiences and works in a simplified way, highlighting year, name of the work, quantity, manipulation technique and reference of institution that manages the action. All actions were coordinated and directed by present author.

2005 - “Banda GTPo”(figs. 04 e 18)- 07 híbridos, meio "sucanecos" e bonecos de Fios - Instituto Francisca de Sousa Peixoto - Cataguases/MG, Brasil. 


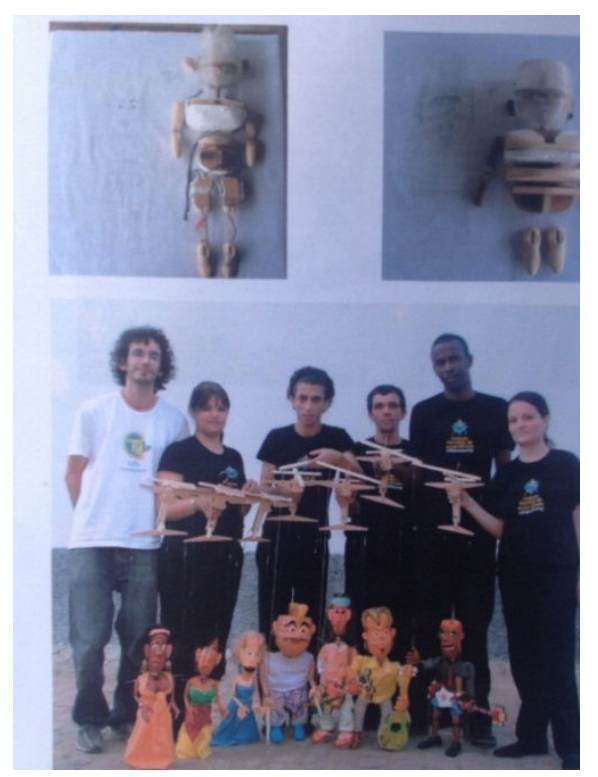

Figure 4. Hibrid construction,"Banda GTPo". Personal archive. (Gustavo Noronha: first from the left)

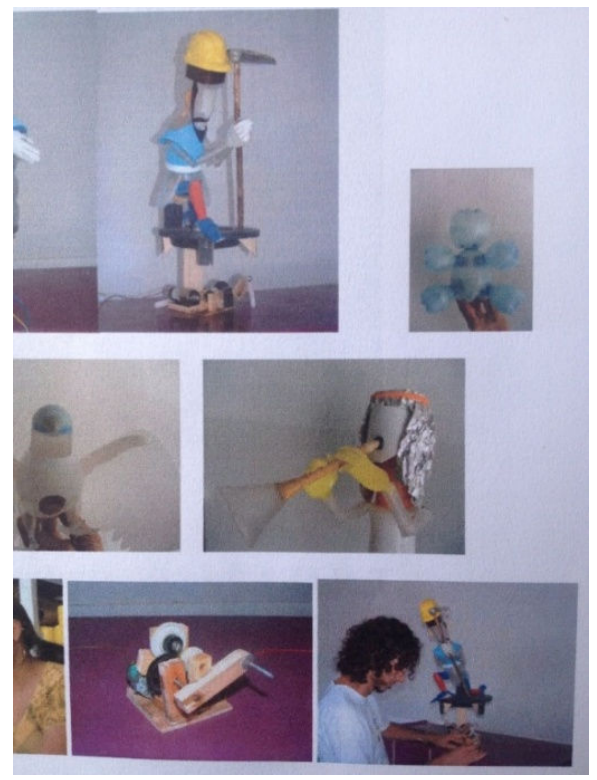

Figure 5. Presépio Móvel, 2005. Personal archive.

2005 - “Presépio Móvel”(Figs. 01, 02, 05, 15 e 19)- 06 "sucanecos" Autômatos - Instituto Francisca de Sousa Peixoto - Cataguases/MG, Brasil.

2006 - “Maritaca BGB”- Bonecos Gigantes de Brazópolis(Figs. 13, 14 e 05) - 01 "sucaneco" de Balcão - Associação Oficina Roda Terra Brazópolis/MG,Brasil.

2006 - “Elefante" - 01 "sucaneco" de fio autoral.

2007 - Curso de "Sucanecos"(fig. 03) para professores da rede pública de ensino da cidade de Cristina/MG ministrado pela Associação Oficina Roda Terra de Braózopolis/MG.
2008 - “A Vaca” - 01 “sucaneco” Habitável Associação Oficina Roda Terra - Brazópolis/ MG.

2009 - “O Alienista” (fig. 06) - 25 "sucanecos" de Luva e Vara - Associação Oficina Roda Terra - Brazópolis/ MG.

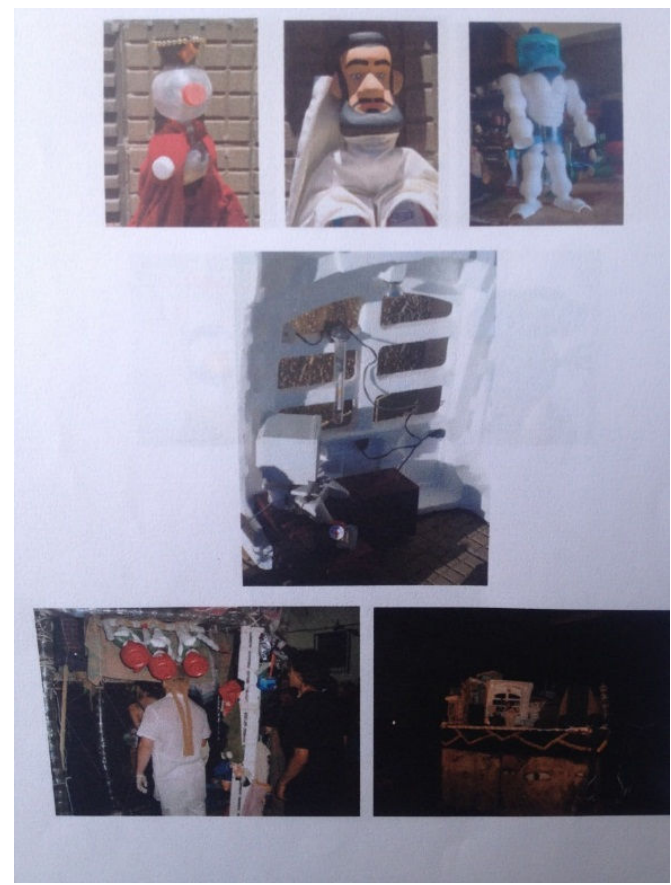

Figure 6. O Alienista, 2009. Personal archive.

2009 - “Educanecos"(Figs. 07, 08 e 09)curso em 52 cidades da rede pública de ensino do Sul de Minas Gerais ministrado pela Associação Oficina Roda Terra de Brazopolis/MG.

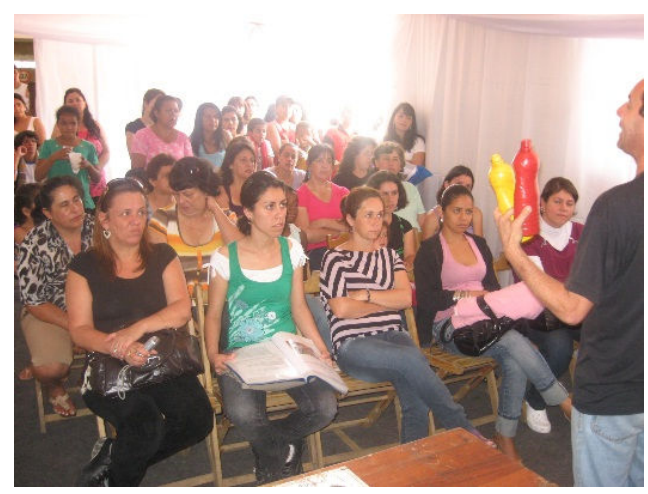

Figure 7. Educanecos, 2009. Personal archive. 


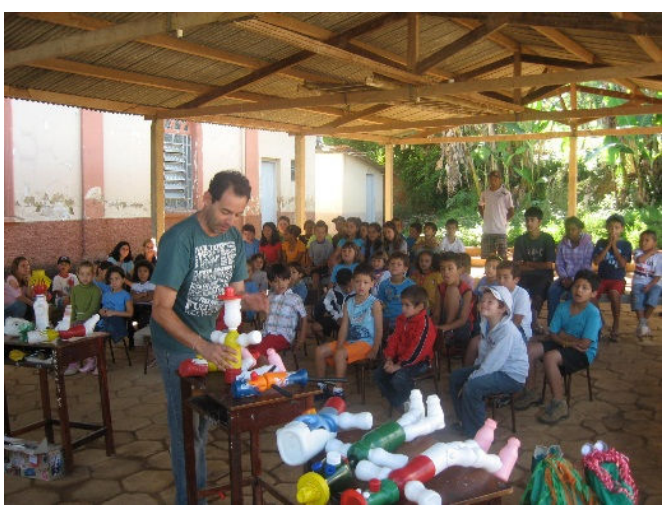

Figure 8. Educanecos, 2009. Personal archive.

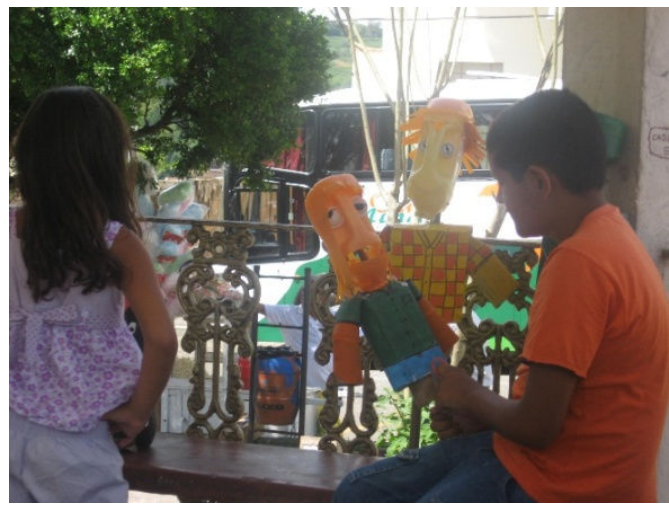

Figure 9. Educanecos, 2009. Personal archive.

2010 - “O Cavaleiro e o Dragão” - 04 "sucanecos" de Vara - Espaço Cultural Casa dos Bonecos - Poços de Caldas/MG.

2011 - "Palhaços"(fig. 10)- 02 "sucanecos" de fio - Espaço Cultural Casa dos Bonecos - Poços de Caldas/MG.

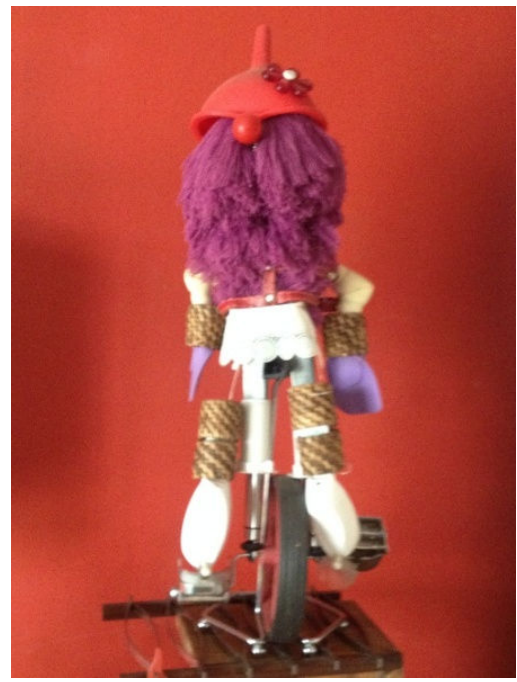

Figure 10. Palhaço, 2009. Personal archive.
2012 - “A Mala do Tesouro"(fig. 16) - 10 "sucanecos" de diversas técnicas de manipulação Espaço Cultural Casa dos Bonecos - Poços de Caldas/MG.

2013 - “O Menino Mutante” - remontagem (fig. 11) - 20 "sucanecos" de Sombras e diversos objetos - Instituto Francisca de Sousa Peixoto Cataguases/MG (2005), Brasil e Espaço Cultural Casa dos Bonecos - Poços de Caldas/MG.

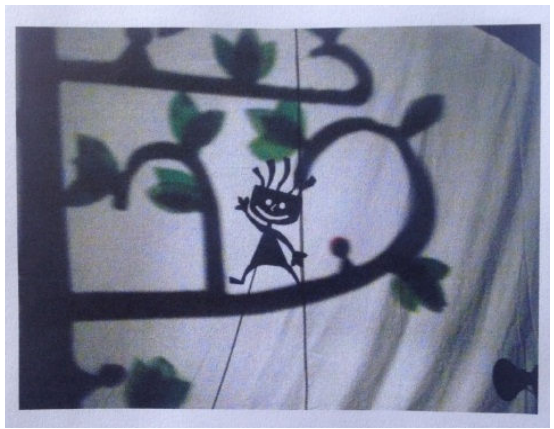

Figure 11. O Menino Mutante, 2005. Personal archive.

2014 - “Vênus" - "sucanecos" conceituais de objetos e corpo humano - Espaço Cultural Casa dos Bonecos - Poços de Caldas/MG.

2014 - "Manifestação popular- Boi"(fig. 12) - 05 "sucanecos" Habitaveis - Espaço Cultural Casa dos Bonecos - Poços de Caldas/MG.

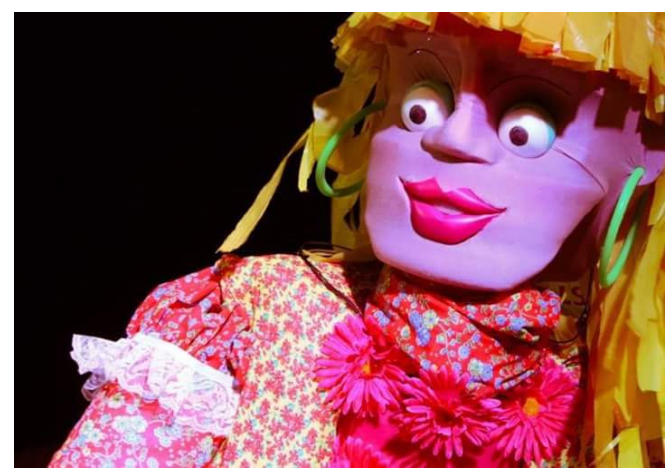

Figure 12. Manifestação Popular - Maricota. Personal archive.

2015 - “Vivaldinos e os Ditos Populares" 08 "sucanecos" Colossais de Carros Alegóricos Carnavalescos - Escola de Samba Vivaldinos da Vivalde - Poços de Caldas/MG.

All actions prove that "sucanecos" research thesis were fully achieved, with wide acceptance of those involved. It has been proved that it is possible to build a whole universe of consistent theater in animated forms (characters, scenarios, costumes, props, 
technical equipment and mechanisms) without the need to buy virtually any material. At zero cost production, using simple mechanisms and homemade tools, a infinity of cosmologically distinct allegories have been born.

\section{Discussion}

Does a scrap work have less "merit" than a work with new materials and purchased under tailor made? A classic puppet with realistic details can be easily done by $3 \mathrm{D}$ printers, but we question if a work with reused material isn't significantly personalized with a social-anthropological identity complex as it always subjects directly to a revolutional change in modern consume market (VALADARES, 2012). As the scraps are conditioned to the "fashionable" products dictated by industrial and commercial conglomerates, thus, periodically, always being exchanged/modified, we see that "Sucanecos" goes along with the world material proliferation, always adopting gratuitous new "raw materials".

The challenge of shape and colour brought by different packs avoid "garbage aesthetics". The common question when presenting the concept of "Sucanecos" to a layman is that the final product would continue with the aesthetics of garbage, but when and full-term "Sucaneco" is shown, people promptly understands the power of the shape and colour of the packaging, when placed in it's own perfect ornamentation proposal.

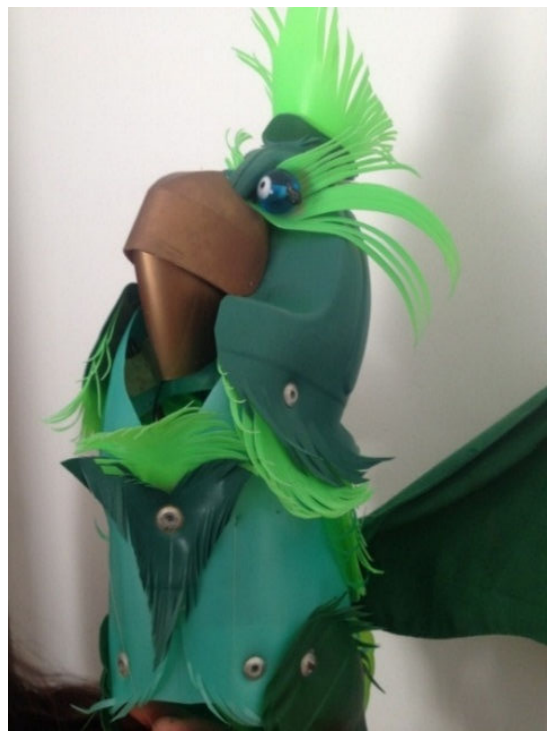

Figure 13. Maritaca BGB, 2006. Personal archive.

In their first impressions, the "Sucanecos" should refer the audience to the character or it's scenic function and, ultimately, remind the observer to be dazzled by finding that all this is done with "leftovers", from materials accessible in their own homes and job. Thus they discover that it would be made of expensive materials if they were bought for such a function.

Polycarbonate, polymers, polyurethanes of various densities, paper, cardboard, rubber, glass, metals, motors, mechanisms, electronics, controls, fabrics, organic materials, stones, old toys and all other scrap generate an infinite amount of raw material for "Sucanecos".

The repulsion and preconception in dealing with "garbage" that make those who work with it seem to be in a less noble or even disgusting activity, is quickly abandoned when we resignify the very concept of junk by applying the concept of "Sucanecos."

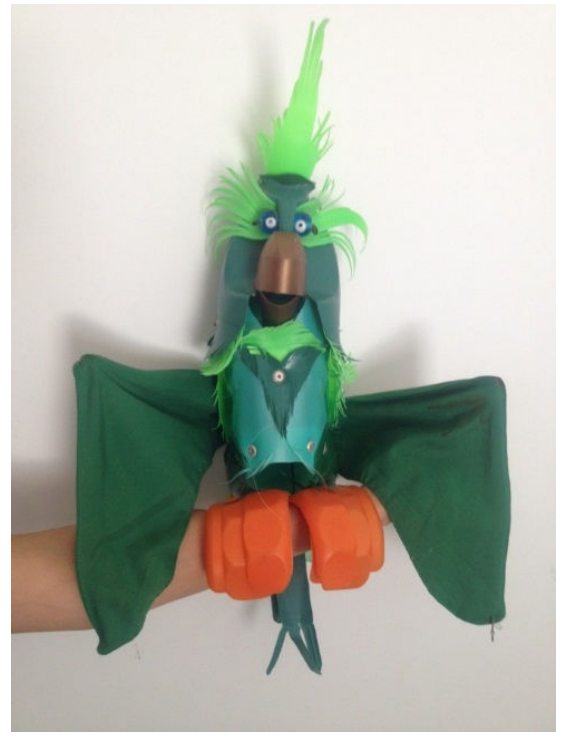

Figure 14. Maritaca BGB, 2006. Personal archive.

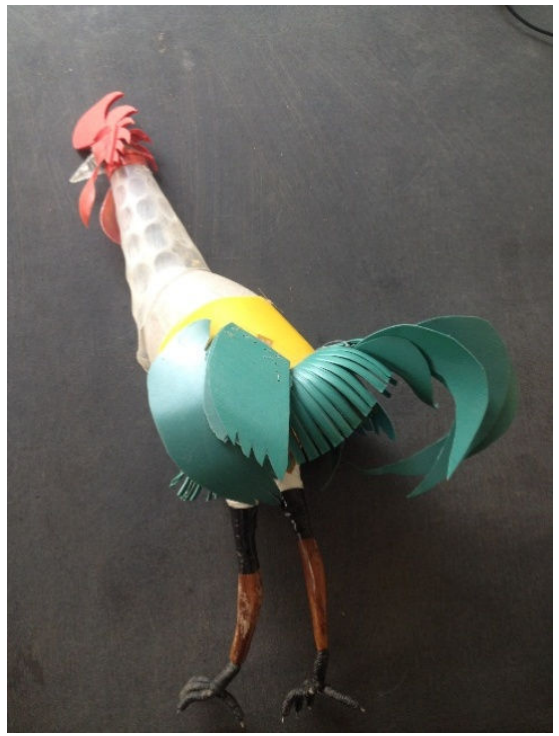

Figure 15. Galo - Presépio Móvel, 2017. Personal archive.

But how would packaging arrive at the right people or would they be limited to creations only with local material? Example of a school that always buys the 
same products for the canteen and general services, as well as the students in their homes have a shopping pattern. In this scenario the "sucanecos" in a short time become repetitive and standardized, good for the commerce through the series production, but lousy for the creative process and educative purposes.

Will be there an apostille? No! Everyone will create their own "methodology" within the universe of possibilities of their environment, their routine, their society, their interest and, above all, their consumption pattern. The courses, workshops and lectures were targeted to the most eclectic audience possible. Diversity has proved fruitful in creative processes due to the healthy coexistence of knowledge and experiences. The more people with different habits and consumption, the greater the variety of materials that facilitated the creation and production of the works.

Is it possible to make a Handbook of Sucanecos? The manual would replicate the research concept if it were handwritten, illustrated and bound by the students themselves, with the materials they know and have available in the region where they live and are distributed by the local community. It would be more of a "scientific logbook" than a simplistic, copy-writing book.

The problem of quantity: in the assembly of "The Alienist" 800 bottles PETs were used in the construction of a small scenic structure (glove puppet theater structure). Getting this number of bottles in a small town for a single scenario is feasible, but if it were necessary to do ten more scenarios?

There was no stock to work with large quantities of these discarded, clean and undamaged materials. And when we needed them the vast majority of the packages were not usable because of dirt and damage. Thousands of bottles Cubed pets to go back to the industry and a hundred mixed in the garbage formula toward the landfills.

What is the responsibility of the largest producers of these packages - this is a question that always accompanied present research. And it was formulated with the word "packaging" and not "garbage", to define that the degree of responsibility of the company is precisely in the drawer of the designer and not in the notorious trash can.

Another difficulty was the fragmented and disconnected collection of the materials, only when the scraps came directly from the students and their close acquaintances, that they came separated and clean. In all localities the municipal collection of waste damaged the scrap and made the growth of the Sucanecos research unfeasible.

\section{Conclusions}

The captivating power of the "puppet" entity, even more so in this digital world, showed its power in an evident way. The various actions and plural universes where the research was applied proved and enlarged also for adults the affirmation of the estimated artist Álvaro Apocalypse:

"The puppet legitimates information for the child (and adults). He shows no interest, like parents and teachers (bosses, teachers and governments) who are extremely worried and nervous when things do not go as well as they wanted. The doll does not. Still impassive." (APOCALYPSE, p.34)

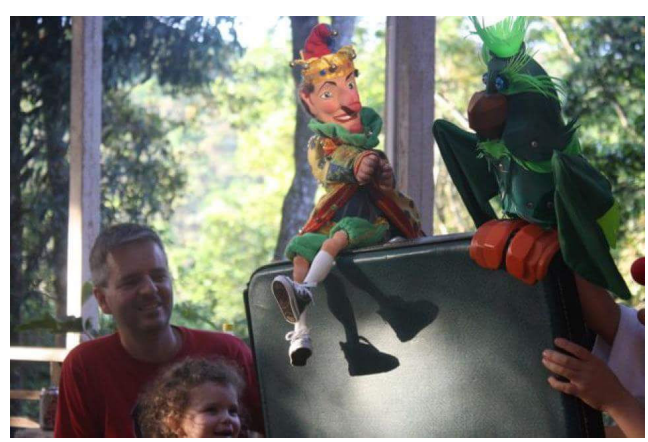

Figure 16. A Mala do Tesouro, 2009. Personal archive.

The conclusion about the controversy of the "handouts" was that it is necessary that the students get the basic information of all the arts before venturing professionally in the universe of the Sustainable Design of the Sucanecos.

The primary notions of colour, form, texture, rhythm, reading, mechanisms, interpretation, singing, coordination, harmony and many other notions and artistic skills should already be in the cultural baggage of each child with primary education, at least, In poorly trained teachers and in the vast majority of self-taught artists. (ONN, 1988)

With this lack of artistic baggage many see the "Sucanecos" as a magical work of trash transformation and not a pedagogical or professional tool that can be conceptually adapted to every need.

A "Sucanecos" manual is different from the conventional pedagogical books of practical laboratory experimentation. The "sucanecos" course has a simple creation methodology, supported by the tripod:

Availability of Materials, in Dramaturgy and in Human Resource.

In the concept of "Sucanecos" there is no duality: Clean things x Dirty things, everything (JUNG, 1964) 
is reused except toxic discard (biomedical wasteand industrial). But to have reuse different materials cannot mix. A classic example is the sandwich served in plastic bags, when discarded no one will separate the rest of corn, potatoes and gravy to reuse the plastic.

This is the formula to create and feed trash landfills. To avoid this polluting formula, it would be enough to replace plastic bags with paper ones, so we would not create garbage, a punctual solution.

In general, the solution would be to give a greater added value to the secondary materials that involve the main product (packaging) making them return to the productive chain with "added value", making possible their differentiated and selective collection.

The research showed how adding artistic and playful values to rejected materials can make these a market product with high economic value. In the theater of animated forms are the work tools of the professional manipulator / actor, in the trade they are sold like toys to inhabit the homes and in classrooms exhibiting their incredible pedagogical powers (BLOIS, 1967).

From the sink to the workshop, and then to the bookshelf, to the stage or to the classroom. This was the cycle that was observed throughout present research. At the beginning of our studies, we were convinced that our greatest difficulty would be to change the habits of people at home in the sink beside the "trash". That they separate the materials and deliver them clean avoiding the garbage formula.

In the cities where the research was applied (Cataguases, Brazópolis, Cristina and Poços de Caldas - Minas Gerais) the acceptance of the concept of "Sucanecos" and the consequent participation of those directly involved, of the institutions and of the local community was immediate. Easy assimilation and replicable to every need. There was also no different acceptance by the municipal education agencies.

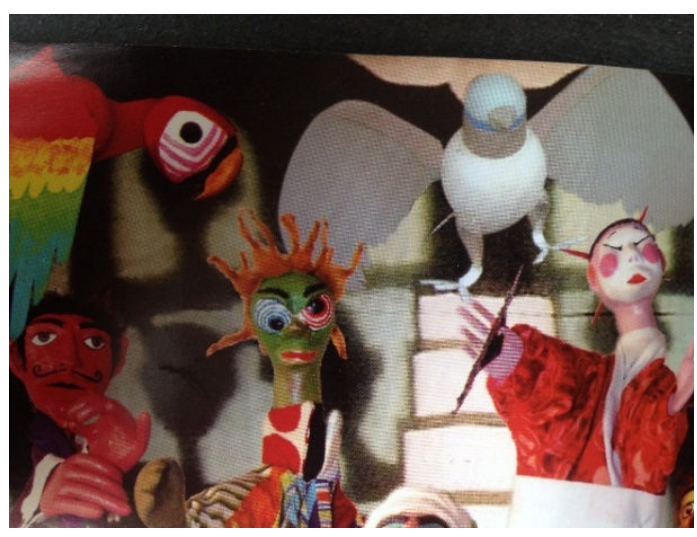

Figure 17. Sucanecos. Personal archive.
Falling to the ground our first conviction and seeing exponentially increase the acceptance of communities we are faced with the first problem, how to do the actions on a commercial and professional scale.

In this chain of reuse and recycling we detect that there is a gap, an empty space, a link in the chain that is missing. Once we fill the gap with this kind of ideas that would significantly reduce the amount of materials in landfills as well as greatly increase the availability of materials for artists, teachers, "sucanequeiro" and so many other professionals and lay people who want to build something using scrap material.

For instance, if a teacher of 4 classes with 30 students wants to pass to the disciples a physics experiment in which they will use 1 pot of margarine and 2 cans of tomato sauce. For everyone to participate she will have to have 120 pots and 360 cans. Here begins the problem, the teacher will have to make a campaign of donation and go storing pots and cans until reaching its goal and then propose the exercise.

The concept of "Sucanecos" can only be replicated by teachers and artists if there is a place where they can pick up their materials quickly, properly, and in large quantities.

Even today it is necessary to "separate" and give ontological significance for the materials so that they do not look like garbage, excluding any bias linked to this job. This professional who emerged exactly in this hiatus, in this limbo of the reuse chain of materials, is wrongly marginalized. They fit the gap in between the industry and the artist, working at the market for example inside this new "sucaneco" concept. In the social aspect this would add better labor conditions for those involved.

In conclusion, in order to solve this hiatus in the cycle of reuse of materials, to social problem of waste pickers, to substantially reduce the materials disposed of in landfills and to make materials available to all interested parties, we propose the creation of Ecosupermarkets offering empty packets and other scraps.

This new urban equipment would enter into the daily routine of the city and urban planning. With a "Supermarket of Empty Packaging and Other Scraps" the responsibility of collecting, storing and distributing this material appropriately is direct remitted to this institution.

Thus professionals and laymen could be willing to easy dispose of various materials. In case there is a refusal of the market to reuse a type of material, the establishment itself forwards the surplus to be recycled by the industry. As well as the workers of this 
enterprise would be exactly the proper collectors of "trash"

The "Sucaneco by kilo" (wholesale). For a certain weight of packaging or scraps that are delivered in this new establishment, the person would earn a discount in the real Supermarket or a gift (toy or Sucaneco).

We also conclude that a sustainable and playful design applied to packaging should be encouraged and recognized by public politics, industrial designers and finally for consumers as a differential factor at the choice of a product.

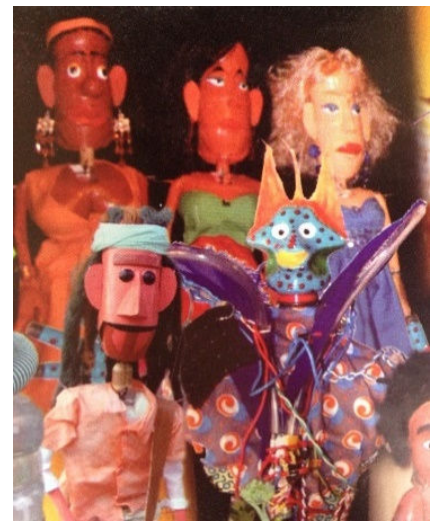

Figure 18. Banda GPTo, 2005. Personal archive.

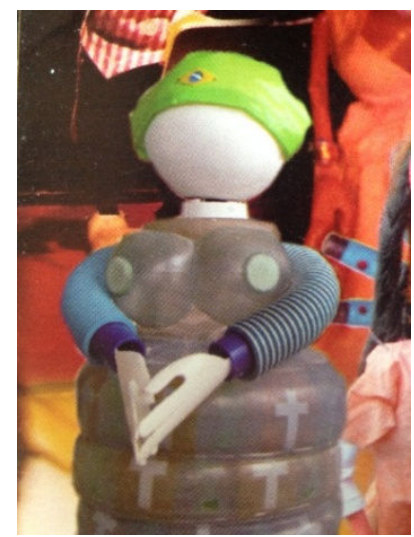

Figure 19. Presépio Móvel - Maria. Personal archive..

\section{Acknowledgments}

Grupo Giramundo Teatro de Bonecos - Belo Horizonte/MG.

Grupo GPTo Teatro de Bonecos - Cataguases/MG.

Instituto Francisca de Sousa Peixoto - Cataguases/MG.

Companhia Industrial Cataguases, mantenedora do projeto GPTo - Cataguases/MG.

Associação Oficina Roda Terra - Brazópolis/MG.

Espaço Cultural Casa dos Bonecos _ Poços de Caldas/MG.

Secretaria de Cultura do Estado de Minas Gerais tendo como agente financeiro o Banco de Desenvolvimento de Minas Gerais - BDMG - através do Fundo Estadual de Cultura - 2007/2008.

Escola de Arquitetura da Universidade Federal de Minas Gerais.

Tradutores Eduardo Da Campos e Fábio Guedes.

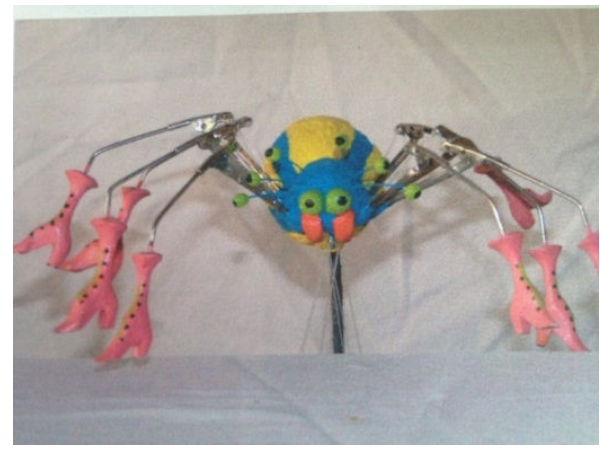

Figure 20. Miss Spider with her hills, construção-hibrida, estudosiniciais, 2005. Personal archive.

\section{References}

AMARAL, Ana Maria. Teatro de Formas Animadas - 2. ed. rev. - São Paulo: Editora da Universidade de São Paulo, 1993.

AMARAL, Ana Maria. O Ator e seus Duplos: Máscaras, bonecos, objetos - São Paulo: Ed. USP SENAC São Paulo, 2002.

APOCALYPSE, Álvaro. Dramaturgia para a nova forma da Marionete - Belo Horizonte: Editora da Escola das Artes da Marionete, 1996.

BetTelheiM, Bruno. A Psicanálise dos Contos de Fadas - 21. ed. rev. - São Paulo: Edtora Paz e Terra, 2007.

BLOIS, Marlene Montezi e BARROS, M. Alice Ferreira. Teatro de Fantoches na Escola Dinâmica Rio de Janeiro: Editora Ao Livro Técnico S.A., 1967. 
BOEUF, Patrick le. Craig et la Marionnette - Paris: ActesSud / BibliothèqueNationale de France, 2009.

CURRELL, David. Making and Manipulating Marionettes - London: EditoraTheCrowood Press, 2010.

FERNANDES, Mario Sergio. O Menino Mutante Brasilia: Editora Exemplus Comunicação e Marketing, 2003.

JUNG, Carl G..O Homem e seus Simbolos - Rio de Janeiro: Editora Nova Fronteira, 1964.

LECOMTE, Jean-Marie e FLASCHGO, Patrick. D'Ombres et de Lumières: Festival MondialdesThéâtres de Marionnettes de ChalevilleMézières. Charleville-Mézière: ÉditionsNoires Terres, 2011.

MATEUS, Alfredo Luís. Química na Cabeça: experiências espetaculares para você fazer em casa ou na escola - Belo Horizonte: Editora UFMG, 2001.

MÓIN - MÓIN: REVISTA DE ESTUDOS SOBRE TEATRO DE FORMAS ANIMADAS. Tradição e Modernidade no Teatro de Formas Animadas Jaraguá do Sul: SCAR/UDESC, ano 2, v.2, 2006.

MÓIN - MÓIN: REVISTA DE ESTUDOS SOBRE TEATRO DE FORMAS ANIMADAS. Teatro de Bonecos Popular Brasileiro - Jaraguá do Sul: SCAR/UDESC, ano 2, v.3, 2007.

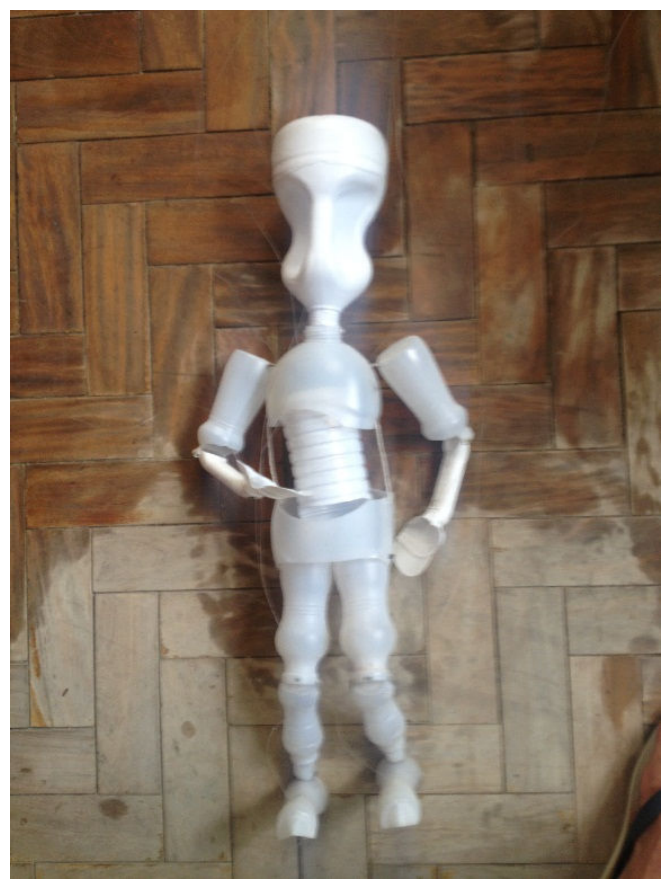

Figure 21. Sucaneco, 2016.
MÓIN - MÓIN: REVISTA DE ESTUDOS SOBRE TEATRO DE FORMAS ANIMADAS. Teatro de Formas Animadas Contemporâneo - Jaraguá do Sul: SCAR/UDESC, ano 3, v.4, 2007.

MÓIN - MÓIN: REVISTA DE ESTUDOS SOBRE TEATRO DE FORMAS ANIMADAS. Teatro de Formas Animadas e sua relação com as outras Artes - Jaraguá do Sul: SCAR/UDESC, ano 4, v.5, 2008.

ONN, Aidan Lawrence e ALEXANDER, Gary. Cabaret Mechanical Movement: Understanding and making Automata - London: Editora CMT BOOK, 1998.

VALADARES, Eduardo Campos. Física Mais que divertida: inventos eletrizantes baseados em materiais reciclados e de baixo custo - 3. ed. ver. e ampl. - Belo Horizonte: Editora UFMG, 2012. 